\title{
Развитие автотранспортной архитектуры Москвы в конце 1930-х годов: деятельность 10-й Архитектурно-проектной мастерской Моссовета
}

\author{
О.С.Шурыгина, Москва
}

Статья посвящена малоизученной теме организации проектирования объектов московской автотранспортной инфраструктуры (преимущественно гаражей) в предвоенные годы. Эта работа в значительной степени возлагалась на одну из номерных архитектурно-проектных мастерских Московского городского совета (Моссовета) - 10-ю - под руководством архитектора В.Д. Кокорина. В статье описаны и проанализированы причины, по которым в конце 1930-х годов перед московскими властями остро встал вопрос о модернизации процесса проектирования автотранспортных объектов, налаженного в начале десятилетия, а также рассмотрена законодательная база этой модернизации. В частности, определяющую роль в подходе к архитектурному решению гаражей и других объектов автотранспортной инфраструктуры сыграла необходимость исполнения требований, содержавшихся в постановлениях Совета народных комиссаров (СНК) СССР «0 генеральном плане реконструкции Москвы» (1935) и «0б улучшении проектного и сметного дела и об упорядочении финансирования строительства» (1938). Главное же внимание автора статьи сфокусировано на самой проектной деятельности 10-й мастерской в хронологических границах 1938-1940 годов. Объектами проектирования этого творческого коллектива являлись не только здания гаражей, но и авторемонтные заводы, автозаправочные станции и троллейбусные парки. Каждая из этих проектных задач требовала учёта многочисленных технологических факторов, в связи с чем внутри мастерской было создано специальное инженерное бюро. Это исключало необходимость кооперации с другими проектировочными организациями, давая 10-й архитектурно-проектной мастерской Моссовета известную самостоятельность. Большая часть проектов получила осуществление. Благодаря архивным изысканиям, удалось уточнить ведомственную принадлежность объектов, установить авторство и адреса возведённых зданий.

Ключевые слова: архитектура XX века, 1930-е годы, гараж, архитектурно-проектные мастерские Моссовета, транспортная архитектура, архитектура Москвы, московский транспорт, организация проектирования.

Development of Moscow's Motor Transport Architecture in the Late 1930s: Activities of the 10th Architectural and Design Studios of the Moscow City Council

0.S.Shurygina, Moscow

The article is devoted to the poorly studied topic of organizing the design of Moscow motor transport infrastructure facilities (mainly garages) in the pre-war years. In general, this work was assigned to one of the numbered Architectural and Design Studios of the Moscow City Council (Mossovet), to wit 10th, headed by architect Victor Kokorin. In the article some aspects of activity of the studio are described and analyzed. Firstly, the reasons why, at the end of the 1930s, the Moscow authorities were faced with the urgent question of modernizing the process of designing motor transport facilities, established at the beginning of the decade. Secondly, the legislative basis for this modernization - in particular, the influence on the architectural design of the facades of buildings of the decrees "On the general plan for the reconstruction of Moscow" (1935) and "On improving the design and estimate business and on streamlining the financing of construction" (1938), worked out by the Council of People's Comissars of USSR. A main attention of the author is focused on the very design activities of the 10th Studio within the chronological boundaries of 1938-1940. The Studio's architects established decisions for automotive garages, auto repair plants, gas stations and also trolleybus depots. Each of these purposes took some special technological conditions, so there is own engineer department in the Studio was organized. Most of the projects were implemented. Thanks to archival research, it was possible to clarify the departmental affiliation of the objects, to establish the authorship and addresses of the erected buildings.

Keywords: 20th century architecture, 1930s, garage, architectural and design studios of the Moscow City Council, transport architecture, architecture of Moscow, Moscow transport, design organization.

23 сентября 1933 года вышло постановление Московского комитета ВКП(б) и президиума Моссовета «0б организации дела проектирования зданий, планировки города и отвода земельных участков в г. Москве» [1]. Документ закреплял новую систему организации проектирования в столице, в рамках которой были созданы десять архитектурно-планировочных и столько же архитектурно-проектных номерных мастерских. За прошедшие с этого момента почти девяносто лет их деятельность так и не стала темой какого-либо специального исследования ${ }^{1}$, а единственным общедоступным

${ }^{1}$ Пожалуй, самая известная работа об организации проектирования в СССР И.А. Казуся заканчивается именно 1933 годом [2], а А.Н. Селиванова доводит своё повествование до Всесоюзного съезда советских архитекторов в 1937 году, но отдельно работу мастерских не рассматривает [3]. 
источником информации о разработанных ими проектах являются иллюстрированные брошюры «Работы архитектурнопроектировочных мастерских за 1934 год» (1936) [4], а также каталоги Первомайских и Октябрьских выставок планировки и архитектуры Москвы [5; 6; 7]. Во второй половине десятилетия работа мастерских уже не получала широкой огласки, в периодике тех лет можно обнаружить лишь разрозненные известия об их деятельности.

Не ставя перед собой задачу освещения организации и функционирования всех мастерских, сосредоточим наше внимание на 10-й Архитектурно-проектной мастерской Моссовета и на её работах в области автотранспортной архитектуры. Эта тема была обозначена нами в работе «Гаражи Москвы: автомобильная архитектура 1900-1930-х годов» [8]. Новые архивные материалы и данные печати конца 1930-х годов позволили существенно расширить и дополнить представление о постановке дела проектирования автотранспортных объектов в предвоенной Москве.

Нужно сказать, что гаражи, построенные для Московского коммунального хозяйства во второй половине 1920-х годов и ныне прославленные как памятники авангардной архитектуры (речь идёт, в первую очередь, о Бахметьевском автобусном и Новорязанском грузовом гаражах) [9, с. 498], по признанию современников, с функциональной точки зрения были далеки от совершенства. Неудовлетворительность их эксплуатационных характеристик побудила в самом скором времени к поиску иных решений. Возросший автопарк столицы требовал внедрения новых принципов самой организации проектирования объектов, в результате чего в 1930 году при Московском коммунальном хозяйстве была создана специализированная контора Мосгаражстрой, в ведении которой теперь находилась разработка технологических и архитектурный проектов гаражей².

В том же году вышло постановление Совета труда и обороны «0 строительстве гаражей в Москве»³. Документ являлся одним из пунктов проводимой СНК СССР политики по реформированию автотранспортных организаций страны в связи с подготовкой к приёму значительного числа машин после запланированного пуска автомобильного завода в Нижнем Новгороде (с 7 октября 1932 года переименованном в Горький).

Через год после своего создания, в апреле 1931 года, Мосгаражстрой был преобразован в Государственный институт по проектированию гаражей, авторемонтных мастерских и автотранспортных предприятий (Гипроавтотранс), в ведении которого находились вопросы рационализации производственных циклов и выстраивания чёткой последовательности производимых в гараже операций по обслуживанию и ремонту автотехники [10]. После создания инженерами-транспортниками оптимальной технологической схемы к работе

\footnotetext{
2 ЦГАМО. Ф. 2157. 0п. 1. Д. 545. Л. 15-16.
}

${ }^{3}$ ГАРФ. Ф. Р5446. 0п. 1. Д. 171. Л. 4. должны были подключаться архитекторы. Тандем инженера и архитектора был обусловлен требованиями столичных властей к архитектурному оформлению московских зданий, и гаражи не были исключением. Это требование было закреплено постановлением СНК СССР и ЦК ВКП(б) «0 генеральном плане реконструкции Москвы» 1935 года: «В связи с генеральной реконструкцией Москвы повысились требования к гаражному строительству, как в отношении его архитектурного оформления, так и отношении этажности» [11, с. 28], - отмечал главный инженер проектов Гипроавтотранса Лев Николаевич Давидович. Для решения специальных архитектурных задач, а именно - к архитектурному оформлению фасадов, и привлекались специалисты номерных мастерских Моссовета.

Так, в сотрудничестве с Архитектурно-проектной мастерской № 2 были выполнены проекты гаражей Народного комиссариата финансов (В.И. Курочкин, А.И. Здрок, 1933-1934; его вторая очередь была выполнена в 1938-1939 годах теми же авторами, но уже в рамках мастерской № 4) и Народного комиссариата лесной промышленности (В.И. Курочкин, А.И. Здрок, 1939); № 3 - 5-го таксомоторного парка таксомоторно-автобусного треста Мосавтотранса (М.А. Минкус, Л.Н. Давидович, П.Г. Капланский, 1936), гаража ЦИК СССР и ВЦИК (М.А. Минкус, Л.Н. Давидович, Л.В. Варзар, 1935-1941), гаража Государственного банка СССР (А.А. Журавлёв, 1939); № 8 гаража издательства ЦК ВКП(б) «Правда» (А.В. Юганов, (?) Богачёв, 1933); № 11 - гаража Государственного всесоюзного объединения по снабжению автомобильным имуществом и его ремонту (Авторемснаб; А.К. Буров, Ю.Н. Емельянов, Ю.С. Фельзер, Н.П. Крымский, 1934). Однако наибольшую известность получили работы 7-й мастерской под руководством К.С. Мельникова: гараж акционерного общества «Интурист» (В.И. Курочкин, К.С. Мельников, Л.Н. Давидович, 1934-1937), гаражи Государственной плановой комиссии, Академии наук и Главного управления Северного морского пути (В.И. Курочкин, К.С. Мельников, А.И. Здрок, 1935-1936, последний - 1936), гараж Исполнительного комитета Коммунистического интернационала (0.П. Макарова, М.М. Бергман, 1936-1937).

Тем не менее даже в такой, казалось бы, налаженной системе проектирования к середине 1930-х годов наметился кризис. Выработанные Мосгаражстроем в начале десятилетия принципы рационального размещения большого количества крупногабаритной техники к его середине уже устарели. В декабре 1936 года президиум Моссовета своим специальным постановлением забраковал разработанные проекты новых гаражей для коммунального транспорта, тем не менее оставив открытым вопрос о дальнейшей рационализации гаражного проектирования [12]. Начатые постройкой объекты были законсервированы [13]. Вновь встал вопрос о «создании специальной организации по проектированию и строительству гаражей» [12]. Скорее всего, после ликвидации Гипроавтотранса весной 1936 года взявший на себя его функции Всесоюзный научно-исследовательский институт промышленного транспорта (ВНИИПТ) так и не смог справиться с объёмом работ. 
Весной 1938 года вышло постановление СНК СССР «0б улучшении проектного и сметного дела и об упорядочении финансирования строительства», которым, в частности, запрещалось применение в промышленных и инфраструктурных объектах дорогостоящих отделочных материалов, декоративных украшений, портиков, барельефов, скульптуры, росписей и даже сплошной штукатурки внешних и внутренних кирпичных стен [14]. Это отразилось и на проектировании московских гаражей, хотя, с другой стороны, требование к художественному оформлению фасадов сохранялось. Эта коллизия открывала интересные возможности для архитекторов: предполагалось создание монументальных, художественно выразительных образов минимальными средствами.

В том же 1938 году была расформирована руководимая К.С. Мельниковым мастерская № 7, тогда основные работы по гаражному проектированию сосредоточились в Архитектурнопроектной мастерской № 10, внутри которой было создано специальное бюро из архитекторов и инженеров, где по заданиям Транспортного управления Моссовета производилось проектирование гаражей, стоянок, авторемонтных мастерских и других объектов автотранспортной инфраструктуры столицы [15; 16]. После упразднения ВНИИПТ в январе 1939 года проекты гаражей, как правило, разрабатывались мастерской в кооперации с Технологическим бюро по проектированию гаражей и авторемонтных заводов, руководителем которого был инженер А.И. Здрок.

Чертежи гаражей конца 1930-х годов, изученные нами в ЦГА г. Москвы, чаще всего были заверены подписью архитектора Н.М. Курочкина ${ }^{4}$, хотя официальным руководителем 10-й мастерской был В.Д. Кокорин. Заместителем Н.М. Курочкина являлся архитектор Н.П. Налётов, главным инженером - М.С. Каменкович. Практически во всех проектах в качестве технолога принимал участие инженер М.М. Бергман. Но в роли авторов конкретных проектов выступали различные архитекторы: Д.В. Разов, И.А. Звездин, А.И. Антонов, (?)Крестин, И.[И.?] Комаров, Вл. Альтшулер, [Г.И.?] Луцкий, А.И. Зеренин, М.В. Аполлонов и группа инженеров под руководством К.Н. Иванова [16].

Нам известно по крайней мере об одиннадцати проектах гаражей, разработанных сотрудниками 10-й мастерской -это проект реконструкции грузовой автобазы в Столярном переулке под 10-й таксомоторный парк (1940), проект многоэтажного таксопарка на улице Большие Кочки (1939), проекты двух гаражей Управления автогрузового транспорта Моссовета (Мосавтогруз; 1938-1939), три типовых таксопарка на Соколиной горе, Бутырском хуторе и в Хорошёво (все проекты 1938 года) и проекты четырёх служебных стоянок: ЦК ВКП(б), Народного комиссариата земледелия ${ }^{5}$, завода № 58 и Глав- ного управления лагерями (ГУЛаг) Народного комиссариата внутренних дел (проекты 1939-1940 годов).

Бо́льшая часть планируемых к постройке объектов предназначалась для коммунального транспорта. Такое фокусирование именно на стоянках городского хозяйства было продиктовано тем, что с начала 1930-х годов (то есть после возведения гаражей, спроектированных Мосгаражстроем), нового строительства автомобильные хозяйства Москвы не вели. А между тем к концу 1939 года ожидалось увеличение автопарка столицы до шестидесяти тысяч машин [12]. Для хранения такого количества техники за несколько лет необходимо было построить несколько десятков многоместных стоянок. Эти планы не были осуществлены.

В наиболее бедственном положении оказались такси. Численность московских таксомоторов за один только 1938 год возросла почти в четыре раза: с примерно 1200 до 5400 машин [17]. Мест катастрофически не хватало [18; 19], фактически в городе действовали три площадки для хранения машин - одноэтажные Гороховский и Крымский таксопарки (последний находился под угрозой сноса из-за предполагаемого строительства на его месте комплекса зданий Академии наук (ССР), также заканчивалось строительство многоэтажной парковки 3-го таксомоторного парка Мосавтотранса в Графском переулке, 9. Остальные автомобили предлагалось размещать в специально арендованных для этого помещениях бывших стоянок других московских организаций.

В самом конце 1930-х годов был принято решение о переводе ряда таксомоторных парков на комплектование автомобилями 3иС-101 (порядка 450 машин) взамен более компактных ГАЗ М-1. Кроме того, в июне 1938 года вышло новое постановление Моссовета «0 строительстве гаражей, организации стоянок для такси и подготовке водителей» [20]. Эти мероприятия требовали расширения парковочных площадок, для чего планировалось строительство двух новых гаражей на юго-западе и востоке города, а также реконструкция одного старого грузовой автобазы на Панской улице - для 13-го таксопарка, обслуживающего северо-западные районы города (1939) ${ }^{6}$.

Где именно предполагалось разместить «восточный» гараж, упоминание о котором можно найти в прессе, выяснить не удалось ${ }^{7}$. На юго-западе гараж Мостаксомотора на 340 машин 3иС-101 проектировался в районе улицы Большие Кочки ${ }^{8}$ (рис. 1-4). Проект таксопарка был разработан в 1939 году архитектором Д.В. Разовым и инженером-технологом М.М. Бергманом. Согласно ему, новый таксомоторный гараж предполагался двухэтажным, с эксплуатируемым подвалом и одноэтажной зоной обслуживания. «Архитектурное оформление, - сообщалось

\footnotetext{
${ }^{4}$ Николай Михайлович Курочкин. Не стоит путать его с Владимиром Ивановичем Курочкиным, сотрудником мастерской К.С. Мельникова.

${ }^{5}$ Месторасположение и подробности строительства гаража Наркомата земледелия на 190 машин выяснить не удалось. Упоминание о работе над проектом 10-й архитектурно-проектной мастерской см.: ЦГА г. Москвы, ОХНТД. Ф. Т-2. 0п. 1. Д. 4160. Л. 67.

${ }^{6}$ ЦГА г. Москвы, ОХНТД. Ф. Т-2. 0п. 1. Д. 4160. Л. 66.

${ }^{7}$ Возможно, речь идёт о неосуществлённом проекте 1939 года гаража на Открытом шоссе (ЦГА г. Москвы, 0ХНТД. Ф. Т-2. 0п. 1. Д. 4160. Л. 56).

${ }^{8}$ ЦГА г. Москвы, ОХНТД. Ф. Т-2. Оп. 1. Д. 4160. Примерная современная привязка - Комсомольский проект, 3-я Фрунзенская улица, Хамовнический вал, Фрунзенская набережная.
} 
в пояснительной записке, - вытекает из планового решения - особенно тыловой и боковой фасады. Характер обработки переднего фасада исполнен в сравнительно простых формах, составленных из ритма больших оконных проёмов в средней части» ${ }^{9}$. Въездные рампы были расположены по углам здания, из подвала должны были вести два дополнительных выезда с рампами, их наземные павильоны симметрично фланкировали здание гаража. Помимо таксомоторного на участке также планировалось строительство троллейбусного парка. Но ни гараж, ни троллейбусный парк так и не были осуществлены.

Помимо стоянок для легкового такси в городе намечалось строительство трёх новых грузовых таксопарков, которые должны были расположиться на севере, востоке и западе города - Бутырском хуторе, Соколиной горе (в Мейеровском проезде) и Хорошёвском шоссе соответственно [21; 22]. Таксопарки планировались в непосредственной близости от основных магистралей, но своими фасадами выходили исключительно на

${ }^{9}$ ЦГА г. Москвы, ОХНТД. Ф. Т-2. 0п. 1. Д. 4160. Л. 11.

${ }^{10}$ ЦГА г. Москвы, ОХНТД. Ф. Т-2. 0п. 1. Д. 760 и-м, 8752, 9947-9949.

${ }^{11}$ Здание было снесено в 2013 году.

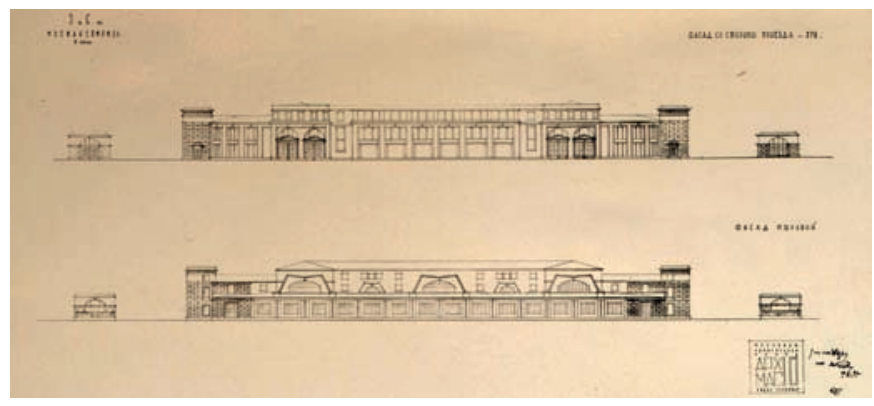

Рис. 1. В.Д. Разов, М.М. Бергман. Проект гаража Мостаксомотора на улице Большие Кочки. Фасады. 1939 год (источник: ЦГА г. Москвы)

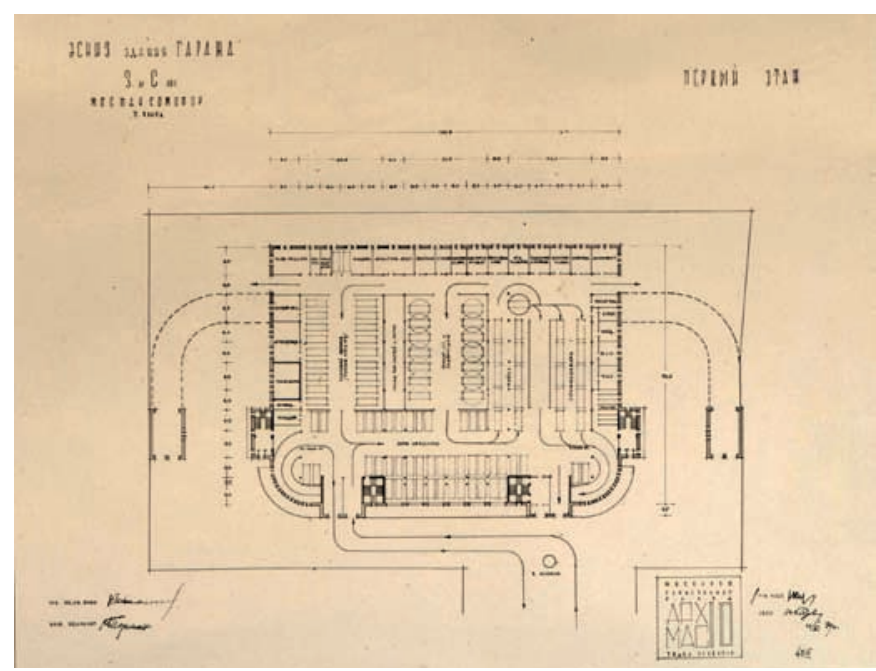

Рис. 3. В.Д. Разов, М.М. Бергман. Проект гаража Мостаксомотора на улице Большие Кочки. План первого этажа. 1939 год (источник: ЦГА г. Москвы) соседние второстепенные улицы. Проекты разрабатывались архитекторами М.В. Аполлоновым и [Г.И.?] Луцким и инженером М.С. Каменковичем по одному типу: гараж на 300 машин с двухэтажным административным корпусом, закрывающим одноэтажную производственную зону со стороны улицы, и открытая стоянка ${ }^{10}$. Грузовой таксомоторный парк на Хорошёвском шоссе, 27 (фасад выходил на 4-ю Магистральную улицу) успели закончить до начала войны ${ }^{11}$. Строительство второго гаража в Мейеровском проезде (современный адрес - проспект Будённого, 51), было начато, но из-за войны завершить его не успели. В 1949-1951 годах площадка будет расширена, на другой стороне Гаражной улицы будет построен дополнительный корпус для обслуживания и ремонта [23]. Закладка таксопарка на Бутырском хуторе, по всей видимости, даже не состоялась.

Следуя уже найденным приёмам, сотрудники 10-й мастерской продолжили развивать новую типологию гаража грузовых машин. В 1939 году архитекторами А.И. Антоновым и А.И. Зерениным был составлен проект гаража для Управления автогрузового транспорта Моссовета (Мосавтогруз) на 250 машин 3иС-5 на 3венигородском шоссе, 25, стр. 1 с двухэтажным административным корпусом, закрывающим одноэтажную про-

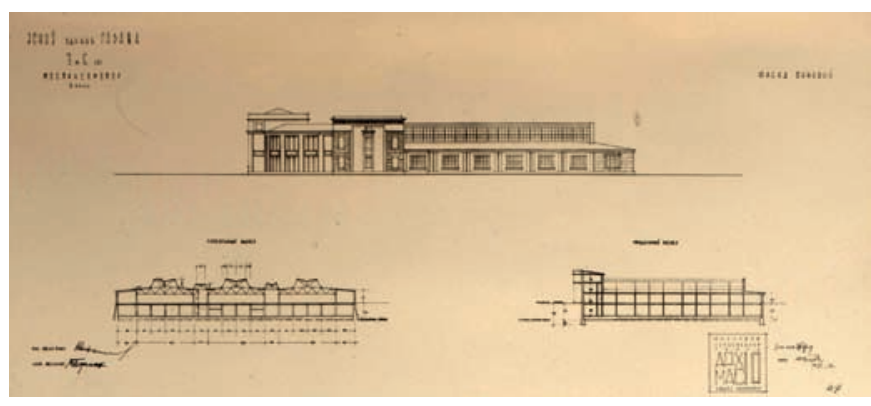

Рис. 2. В.Д. Разов, М.М. Бергман. Проект гаража Мостаксомотора на уличе Большие Кочки. Фасад, разрезы. 1939 год (источник: ЦГА г. Москвы)

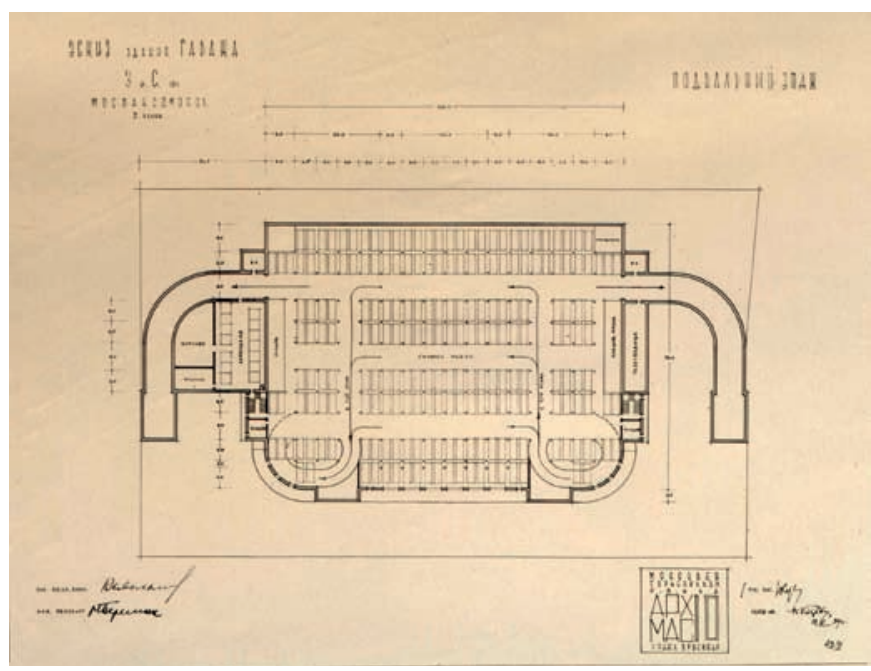

Рис. 4. В.Д. Разов, М.М. Бергман. Проект гаража Мостаксомотора на улице Большие Кочки. План подвала. 1939 год (источник: ЦГА г. Москвы) 
изводственную зону со стороны Красногвардейского бульвара, куда был ориентирован фасад, и открытой стоянкой [24]. Годом ранее А.И. Антонов спроектировал другой гараж Мосавтогруза - на Остаповском шоссе. Но ни графических материалов, ни описания этого проекта нам обнаружить не удалось.

Ведомственные стоянки, спроектированные 10-й мастерской, по сути не отличались от уже разработанных ранее схем. При этом каждый из проектов создавался как авторский. Проектирование гаражей завода № 58 и ГУЛаг НКВД началось в самом конце 1939 года и продолжилось в начале 1940-го. Оба гаража были одноэтажными, рассчитанными на хранение 100 автомобилей каждый, однако технологическая схема расстановки машин и оборудования была разной.

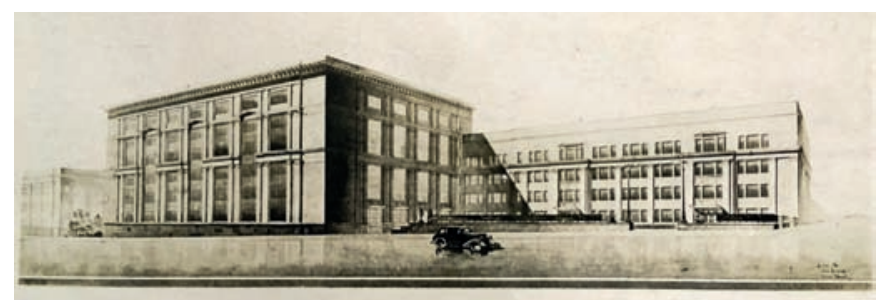

Puс. 5. А.Б. Варшавер, А.И. Здрок при участии Н.А. Асатура и B.Е. Каплана. Проект гаража Управления делами ЦК ВКП(б). Перспектива. 1937-1939 годы (источник: ЦГАНТД СПб)
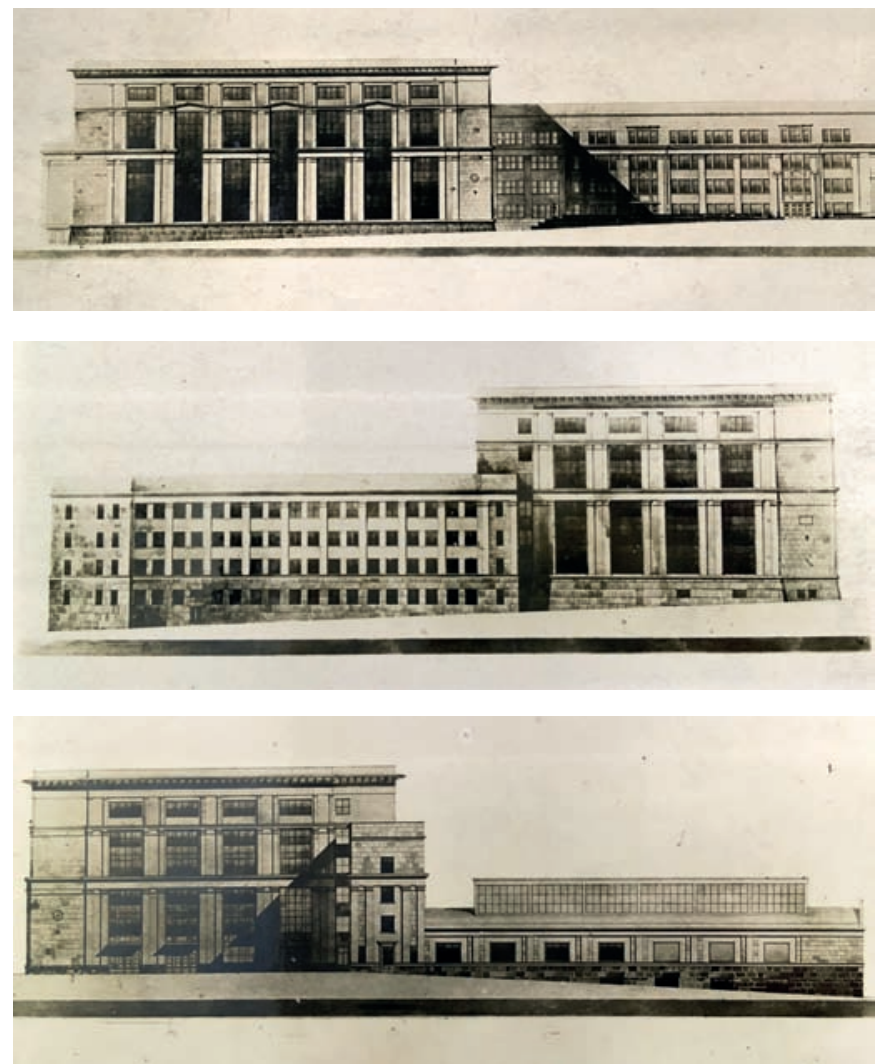

Pис. 6. А.Б. Варшавер, А.И. Здрок при участии Н.А. Асатура и В.Е. Каплана. Проект гаража Управления делами ЦК ВКП(б). Фасады. 1937-1939 годы (источник: ЦГАНТД СПб)
Завод № 58 им. Клима Ворошилова Наркомата боеприпасов располагался на плотно застроенном участке по адресу Проспект Мира, 102. Вероятно, на территории самого завода необходимой площадки не нашлось, поэтому строительство гаража было перенесено на ближайший свободный участок - Звёздный бульвар, 13. Авторами проекта были архитектор И.[И.(?)] Комаров и инженер М.М. Бергман ${ }^{12}$. Протяжённый трёхэтажный административный корпус выходит на красную линию, закрывая собой зону стоянки, примыкающую к нему с тыльной стороны. Помимо стоянки машин в одноэтажном корпусе располагались «профилакторий» (участок текущего технического осмотра), ремонтный зал, производственные цеха, бытовые помещения и котельная, - всё это планировалось перекрыть металлической фермой пролётом 18 м с двумя продольными типовыми трапециевидными фонарями.

«Архитектурное решение здания гаража дано простым по своим формам и членениям с подчёркиванием назначения и характера здания. <...> Здание гаража выполнено из красного кирпича с облицовкой наружных поверхностей стен облицовочным кирпичом с расшивкой швов и частичной штукатуркой отдельных архитектурных элементов карнизов, обрамлений окон, входов и цоколя. Внутренняя поверхность кирпичных стен производственных помещений, стоянки, котельной выполняется также с расшивкой швов без оштукатуривания их, с последующей побелкой известковым раствором» ${ }^{13}$, - такое оформление вполне отвечает требованиям постановления СНК СССР «0б улучшении проектного и сметного дела...». В реальности же не удалось осуществить даже этого: к началу войны успели возвести лишь стены, до перекрытия тогда дело не дошло ${ }^{14}$.

В отличие от предыдущего объекта, гараж ГУЛаг НКВД на 100 автомобилей ГАЗ М-1 и ЗиС-101 на Коленчатой улице, 24-28 (современный адрес - улица Юннатов, 4) ${ }^{15}$ успели закончить к началу войны. Его отличием от гаража завода № 58 являлись пропорции плана, более приближенные к квадрату; стоянка с особым выездом для каждого автомобиля; производственная зона, перекрытая фермой не с двумя, а с тремя фонарями верхнего света. Административный корпус был фланкирован двумя ризалитами. Авторами проекта выступили архитектор Вл. Альтшулер и инженер М.М. Бергман, при участии А.И. Здрока. Здание было снесено в 2018 году.

Последним многоэтажным гаражом, строительство которого удалось (пусть и частично) завершить до войны, была автобаза ЦК ВКП(б) на Звенигородском шоссе, гараж-«люкс», как называли его современники [25]. До этого машины

12 Также в документах встречаются фамилии инженеров Кочетова и Тепмана. ЦГА г. Москвы, ОХНТД. Ф. Т-2. 0п. 1. Д. 2644, 2645.

${ }^{13}$ ЦГА г. Москвы, ОХНТД. Ф. Т-2. Оп. 1. Д. 2644. Л. 22.

${ }^{14}$ В том же 1939 году с южной стороны от гаража был выделен участок под строительство троллейбусного парка (на 160 машин ЯТБ-4), а с северной - для ещё одного гаража (ЦГА г. Москвы, ОХНТД. Ф. Т-2. 0п. 1. Д. 2664. Л. 38), но работы так и не были начаты.

${ }^{15}$ ЦГА г. Москвы, ОХНТД. Ф. Т-2. 0п. 1. Д. 3789; Т-89. 0п. 1. Д. 261. 
партийного руководства занимали построенный в 1936 году гараж в Грохольском переулке, 29. Проектирование центрального партийного гаража на Звенигородском шоссе, 27, стр. 3 началось в 1937 году, но основные работы были проведены в 1938-1939 годы. Проект архитекторов А.Б. Варшавера и инженера А.И. Здрока, при участии архитектора Н.Г. Асатура и инженера В.Е. Каплана предусматривал возведение 6-этажной стоянки на 425 легковых и 50 грузовых автомобилей [26; $27 ; 28$, с. 15,$17 ; 29$, с. 128, 132] (рис. 5, 6)

«Сложным в этой работе является выражение архитектурного образа гаража, - писал А.Б. Варшавер, - очень легко впасть в конструктивизм, ни в коей мере не удовлетворяющий нас. С другой стороны, нельзя ориентироваться на классические формы, которые не отразят характера здания. Я хочу показать, что в архитектуре гаражестроения можно добиться полноценной формы, выражающей функциональное назначение сооружения» [30].

По генеральному плану реконструкции Москвы Звенигородское шоссе планировалось расширить до 65 метров и превратить в магистраль, поэтому гараж, который должен был здесь возникнуть, мог быть только многоэтажным. Вокруг высотной доминанты парковки проектировался целый комплекс вспомогательных сооружений: двухэтажный корпус обслуживания машин, одноэтажные (ожидания и ремонта), трёхэтажный (бытовой) и четырёхэтажный (административно-служебный). Критики из числа современников упрекали архитектуру гаража в излишней «академичности», но особенно обращали внимание на технологические просчёты [31, с. 9]. Из задуманного удалось осуществить лишь многоэтажную стоянку.

Наряду с автомобильными гаражами, 10-я мастерская вела разработку проектов шести новых троллейбусных парков двух типов: на 100 и 160 машин (1938) [32]. Работа была поручена архитектору И.А. Звездину. До войны удалось построить лишь один - 3-й троллейбусный парк в Филях на 160 машин ЯТБ-4 (открыт в ноябре 1940 года) [33].

Помимо гаражей, в 1938-1939 году сотрудниками 10-й мастерской архитекторами И.[И.(?)] Комаровым и Крестиным и инженерами Кочетовым и [Н.И.] Богдановым были составлен проекты двух авторемонтных заводов (на 3200 и 6000 ремонтов в год), один из которых, для машин ГАЗ М-1, должен был разместиться на Открытом шоссе [15; 24]. Кроме того, те же И.[И.(?)] Комаров и Крестин при участии инженера Н.П. Голованова выступили авторами, по крайней мере, двух автозаправочных станций: на 1-й Богатырской улице (1938) (рис. 7) и в Брюсовом переулке $(1940)^{16}$ (рис. 8).

Война внесла существенные коррективы в дело проектирования московских автомобильных гаражей. Выработанный во второй половине 1930-х годов тип репрезентативного гаража, в облике которого производственно-технологическое начало было нивелировано архитектурным монументализмом, в послевоенные годы уже не нашёл применения. В то же время по-

${ }^{16}$ ЦГА г. Москвы, ОХНТД. Ф. Т-2. Оп. 1. Д. 758 г; 671. сле 1940 года в проектировании таких зданий попросту отпала нужда: практически все наркоматы, ведомства и учреждения обзавелись ими в готовом или недостроенном виде. Московские же коммунальные службы в целях экономии предпочли перейти на открытые стоянки для большегрузной техники, оставив под крышей лишь более представительные таксомоторы.

Деятельность 10-й Архитектурно-проектной мастерской Моссовета, впрочем, как и остальных мастерских, нуждается в полноценном историческом исследовании. Наше же внимание было сосредоточено на одном из направлений её деятельности - проектировании объектов автотранспортной инфраструктуры.

\section{Список сокращений}

ВКП(б) - Всесоюзная коммунистическая партия (большевиков)

ВЦИК - Всероссийский центральный исполнительный комитет

ГАРФ - Государственный архив Российской Федерации, Москва

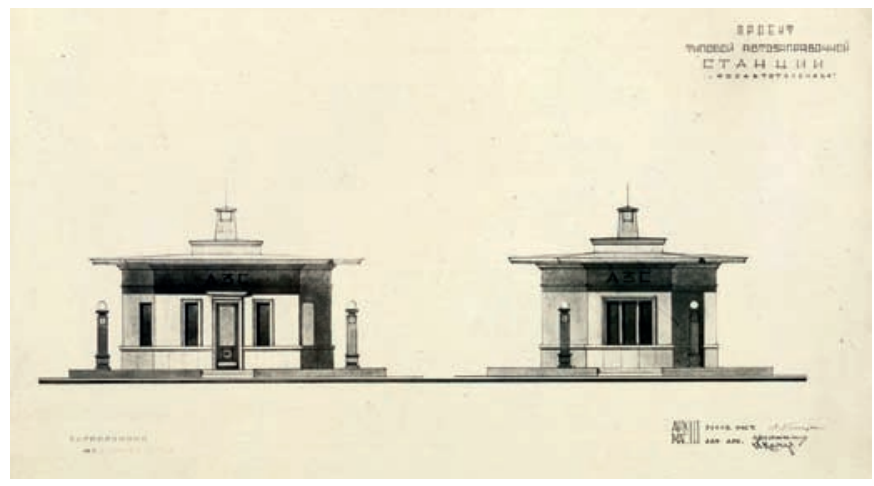

Рис. 7. (?) Крестин, И.[И.?] Комаров, Н.П. Голованов. Проект автозаправочной станции на 1-й Богатырской улище. Фасады. 1938 год (источник: ЦГА г. Москвы)

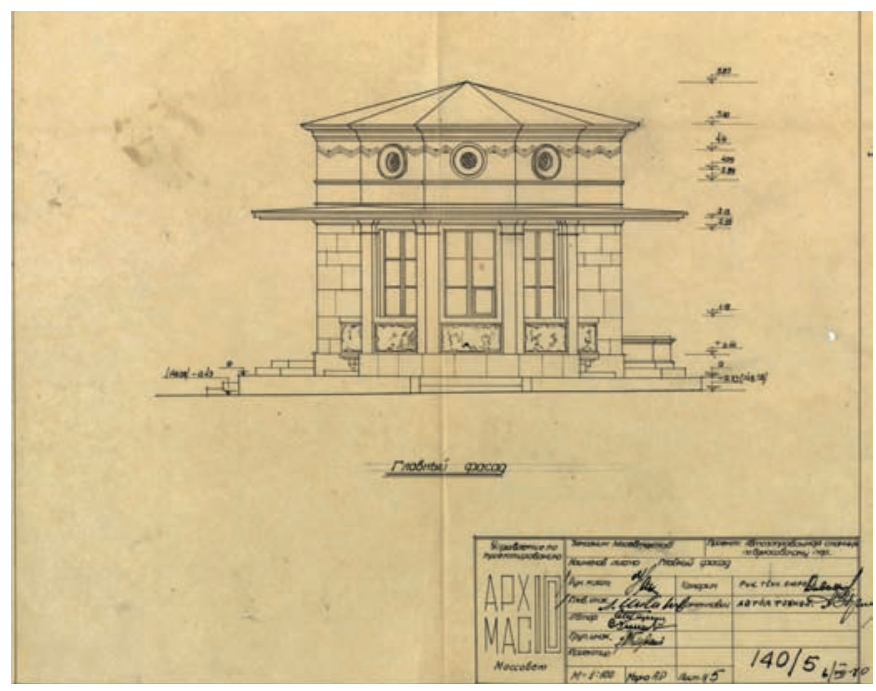

Pис. 8. (?) Крестин, И. [И.?] Комаров, Н.П. Голованов. Проект автозаправочной станции в Брюсовом переулке. Фасад. 1940 год (источник: ЦГА г. Москвы) 
СНК СССР - Совет народных комиссаров Союза Советский Социалистических Республик

СССР - Союз Советский Социалистических Республик

ЦГА г. Москвы, ОХНТД - Центральный государственный архив города Москвы, Отдел хранения научно-технической документации

ЦГАМО - Центральный государственный архив Московской области, Москва

ЦГАНТД СПб - Центральный государственный архив научно-технической документации Санкт-Петербурга

ЦИК СССР - Центральный исполнительный комитет Союза Советский Социалистических Республик

ЦК ВКП(б) - Центральный комитет Всесоюзной коммунистической партии (большевиков)

\section{Лuтература}

1. «0б организации дела проектирования зданий, планировки города и отвода земельных участков в г. Москве». Постановление МГК ВКП(б) и Президиума Моссовета. 23 сентября 1933 г. // Наше строительство. - 1933. - № 20. - С. 511-512.

2. Казусь, И.А. Советская архитектура 1920-х годов: организация проектирования / И.А. Казусь. - М. : Прогресстрадиция, 2009. - 464 с. ISBN 5-89826-291-1.

3. Селиванова, А.Н. Постконструктивизм. Власть и архитектура в 1930-е годы в СССР / А.Н. Селиванова. - М. : БуксМАрт, 2019. - 320 с. ISBN 978-5-6040055-9-0.

4. Работы архитектурно-проектировочных мастерских за 1934 год. - М. : [Б. и.], 1936.

5. Первомайская (2-я) выставка планировки и архитектуры на ул. Горького. - М. : Строительство Москвы, 1934. - 24 С.

6. Октябрьская (3-я) выставка планировки и архитектуры на ул. Горького. - М. : Издательство Моссовета, 1934. - 34 с.

7. Первомайская (4-я) выставка планировки и архитектуры на ул. Горького. - М. : Строительство Москвы, 1935. - 34 С.

8. Шурыгина, О.С. Гаражи Москвы: автомобильная архитектура 1900-1930-х годов / 0.С. Шурыгина. - М. : Еврейский музей и центр толерантности; 000 «Арт Гид», 2020. - 384 с. ISBN 978-5-6043944-4-1.

9. Климович, В. В борьбе за советский гараж / В.И. Климович // Мотор. - 1932. - № 11. - С. 497-506.

10. Теплов, Е. Задачи Гипроавтотранса / Е. Теплов // Мотор. - 1931. - № 6. - С. 30.

11. Давидович, Л.Н. Проекты многоэтажных гаражей в Москве / Л.Н. Давидович // Мотор. - 1936. - № 5. - С. 28-30.

12. Павловский, Г. Автомобильное хозяйство столицы / Г. Павловский // Вечерняя Москва. - 1937. - № 123 (4054). - С. 2.

13. Дембовская, Л. Жильё для автомашин. Строительство гаражей законсервировано / Л. Дембовская // Вечерняя Москва. - 1937. - № 182 (4113). - С. 2.

14. «0б улучшении проектного и сметного дела и об упорядочении финансирования строительства». Постановление СНК СССР // Архитектура СССР. - 1938. - № 4. - С. 2.
15. Кокорин, В. Новые ансамбли / В.Д. Кокорин // Вечерняя Москва. - 1938. - № 245 (4475). - С. 2.

16. Хроника. В Архитектурно-проектных мастерских // Строительство Москвы. - 1939. - № 6. - С. 31.

17. 4200 новых такси // Вечерняя Москва. - 1938. - № 116 (4346). - C. 1.

18. Тихонов, Ю. Такси и гаражи. 80 машин ждут хозяина / Ю. Тихонов // Вечерняя Москва. - 1937. - № 218 (4149). - С. 2.

19. Навести порядок в тресте «Мостаксомотор» // Вечерняя Москва. - 1939. - № 14 (4543). - С. 3.

20. Тысячи такси. Гаражи под мостами // Вечерняя Москва. - 1938. - № 146 (4376). - С. 3.

21. База грузовых такси // Вечерняя Москва. - 1938. - № 243 (4473). - C. 2.

22. Ивахненко, В. Строительство гаражей затягивается / В. Ивахненко // Вечерняя Москва. - 1939. - № 41 (4570). - С. 2.

23. Строительство гаражей // Городское хозяйство Москвы. - 1949. - № 5. - С. 33.

24. Ансамбли на магистралях // Вечерняя Москва. - 1939. - № 223 (4752). - С. 2.

25. Шестиэтажный гараж на 500 машин // Вечерняя Москва. - 1937. - № 214 (4145). - С. 2.

26. Многоэтажные гаражи // Архитектурная газета. - 1939. - № 10. - C. 4.

27. Автомашина на 6-м этаже // Вечерняя Москва. - 1939. - №. 221 (4750). - С. 2.

28. Минкус, М. Многоэтажные гаражи в СССР / М.А. Минкус // Архитектура СССР. - 1940. - № 1. - С. 9-17.

29. Хевелёв, Э.М. Проектирование городских гаражей / Э.М. Хевелёв. - Л. : Госстройиздат, 1961. - 184 с.

30. Варшавер, А.Б. Моя работа над гаражами / А.Б. Варшавер // Архитектурная газета. - 1937. - № 31 (175). - С. 4.

31. Захаров, Г. Проект гаража на 475 автомашин / Г. Захаров, Ю.С. Фельзер // Строительство Москвы. - 1938. - № 5. - С. 7-10.

32.Хроника//Архитектурная газета.-1938. -№5(234). -С.4.

33. Новый троллейбусный парк в Москве // Строительная газета. - 1940. - № 99. - С. 4.

\section{References}

1. «Ob organizatsii dela proektirovaniya zdanii, planirovki goroda i otvoda zemel'nyh uchastkov v g. Moskve». Postanovlenie MGK VKP(b) i Prezidiuma Mossoveta. 23 sentyabrya 1933 g. ["On the organization of the design of buildings, city planning andland allotment in Moscow". Resolution of the Moscow City Committee of the All-Union Communist Party (Bolsheviks) and the Presidium of the Moscow City Council. September 23, 1933]. In: Nashe stroitel'stvo [Our construction], 1933, no. 20, pp. 511-512. (In Russ.)

2. Kazus' I.A. Sovetskaya arhitektura 1920-h godov: organizaciya proektirovaniya [Soviet architecture of the 1920s: design organization]. Moscow, Progress-tradiciya Publ., 2009, 464 p. (In Russ.) ISBN 5-89826-291-1.

3. Selivanova A.N. Postkonstruktivizm. Vlast' i arhitektura v 1930-e gody v SSSR [Postconstructivism. Power and architecture 
in the 1930s in the USSR]. Moscow, BuksMArt Publ., 2019, 320 p. (In Russ.) ISBN 978-5-6040055-9-0.

4. Raboty arhitekturno-proektirovochnyh masterskih za 1934 god [Works of architectural and design workshops for 1934]. Moscow, 1936. (In Russ.)

5. Pervomajskaya (2-ya) vystavka planirovki i arhitektury na ul. Gor'kogo [May Day (2nd) exhibition of planning and architecture on the Gorky Street]. Moscow, Stroitel'stvo Moskvy Publ., 1934, 24 p. (In Russ.)

6. Oktyabr'skaya (3-ya) vystavka planirovki i arhitektury na ul. Gor'kogo [0ctober (3rd) exhibition of planning and architecture on the Gorky Street]. Moscow, Mossoveta Publ., 1934, 34 p. (In Russ.)

7. Pervomajskaya (4-ya) vystavka planirovki i arhitektury na ul. Gor'kogo [May Day (4th) exhibition of planning and architecture on the Gorky Street]. Moscow, Stroitel'stvo Moskvy Publ., 1935, 34 p. (In Russ.)

8. Shurygina 0.S. Garazhi Moskvy: avtomobil'naya arhitektura 1900-1930-h godov [Moscow garages: automobile architecture of the 1900s-1930s]. Moscow, Jewish Museum and Tolerance Center; 000 «Art Gid» Publ., 2020, 384 p. (In Russ.) ISBN 978-5-6043944-4-1.

9. Klimovich V. V bor'be za sovetskij garazh [In the struggle for the Soviet garage]. In: Motor [Motor], 1932, no. 11, pp. 497-506. (In Russ.)

10. Teplov E. Zadachi Giproavtotransa [Tasks of Giproavtotrans]. In: Motor [Motor], 1931, no. 6, p. 30. (In Russ.)

11. Davidovich L.N. Proekty mnogoetazhnyh garazhei v Moskve [Projects of multi-storey garages in Moscow]. In: Motor [Motor], 1936, no. 5, pp. 28-30. (In Russ.)

12. Pavlovskij G. Avtomobil'noe hozyaistvo stolicy [Automotive industry of the capital]. In: Vechernyaya Moskva [Evening Moscow], 1937, no. 123 (4054), p. 2. (In Russ.)

13. Dembovskaya L. Zhil'yo dlya avtomashin. Stroitel'stvo garazhei zakonservirovano [Housing for cars. Construction of garages is mothballed]. In: Vechernyaya Moskva [Evening Moscow], 1937, no. 182 (4113), p. 2. (In Russ.)

14. «Ob uluchshenii proektnogo i smetnogo dela i ob uporyadochenii finansirovaniya stroitel'stva». Postanovlenie SNK SSSR ["On improving the design and estimate business and on streamlining the financing of construction". Resolution of the Council of People's Commissars of the USSR]. In: Arhitektura SSSR [Architecture of the USSR], 1938, no. 4, p. 2. (In Russ.)

15. Kokorin V. Novyeansambli [Newensembles]. In: Vechernyaya Moskva [Evening Moscow], 1938, no. 245 (4475), p. 2. (In Russ.)

16. Hronika. V Arhitekturno-proektnyh masterskih [Chronicle. In the Architectural Design Studios]. In: Stroitel'stvo Moskvy [Construction of Moscow], 1939, no. 6, p. 31. (In Russ.)
17. 4200 novyh taksi [4200 new taxis]. In: Vechernyaya Moskva [Evening Moscow], 1938, no. 116 (4346), p. 1. (In Russ.)

18. Tihonov Y. Taksi i garazhi. 80 mashin zhdut hozyaina [Taxi and garages. 80 cars are waiting for the owner]. In: Vechernyaya Moskva [Evening Moscow], 1937, no. 218 (4149), 22 sentyabrya, p. 2. (In Russ.)

19. Navesti poryadok v treste «Mostaksomotor» [Putting things in order in the Mostaxomotor trust]. In: Vechernyaya Moskva [Evening Moscow], 1939, no. 14 (4543), p. 3. (In Russ.)

20. Tysyachi taksi. Garazhi pod mostami [Thousands of taxis. Garages under bridges]. In: Vechernyaya Moskva [Evening Moscow], 1938, no. 146 (4376), p. 3. (In Russ.)

21. Baza gruzovyh taksi [Base of freight taxis]. In: Vechernyaya Moskva [Evening Moscow], 1938, no. 243 (4473), 22 oktyabrya, p. 2. (In Russ.)

22. Ivahnenko V. Stroitel'stvo garazhei zatyagivaetsya [Construction of garages is delaying]. In: Vechernyaya Moskva [Evening Moscow], 1939, no. 41 (4570), p. 2. (In Russ.)

23. Stroitel'stvo garazhei [Construction of garages]. In: Gorodskoe hozyaistvo Moskvy [Municipal economy of Moscow], 1949, no. 5, p. 33. (In Russ.)

24. Ansambli na magistralyah [Ensembles on highways]. In: Vechernyaya Moskva [Evening Moscow], 1939, no. 223 (4752), p. 2. (In Russ.)

25. Shestietazhnyi garazh na 500 mashin [Six-story garage for 500 cars]. In: Vechernyaya Moskva [Evening Moscow], 1937, no. 214 (4145), p. 2. (In Russ.)

26. Mnogoetazhnye garazhi [Multi-storey garages]. In: Arhitekturnaya gazeta [Architectural newspaper], 1939, no. 10, p. 4. (In Russ.)

27. Avtomashina na 6-m etazhe [Car on the 6th floor]. In: Vechernyaya Moskva [Evening Moscow], 1939, no. 221 (4750), p. 2. (In Russ.)

28. Minkus M. Mnogoetazhnye garazhi v SSSR [Multi-storey garages in the USSR]. In: Arhitektura SSSR [Architecture of the USSR], 1940, no. 1, pp. 9-17. (In Russ.)

29. Hevelev E.M. Proektirovanie gorodskih garazhei [Design of city garages]. Leningrad, Gosstrojizdat Publ., 1961, 184 p. (In Russ.)

30. Varshaver A.B. Moya rabota nad garazhami [My work on garages]. In: Arhitekturnaya gazeta [Architectural newspaper], 1937, no. 31 (175), p. 4. (In Russ.)

31. Zaharov G., Fel'zer Y. Proekt garazha na 475 avtomashin [Project of a garage for 475 cars]. In: Stroitel'stvo Moskvy [Construction of Moscow], 1938, no. 5, pp. 7-10. (In Russ.)

32. Hronika [Chronicle]. In: Arhitekturnaya gazeta [Architectural newspaper], 1938, no. 5 (234), p. 4. (In Russ.)

33. Novyi trollejbusnyi park v Moskve [New trolleybus fleet in Moscow]. In: Stroitel'naya gazeta [Construction newspaper], 1940, no. 99, p. 4. (In Russ.)

Шурыгина Ольга Сергеевна (Москва), независимый исследователь, член ICOMOS. Эл. почта: olia85@list.ru.

Shurygina 0lga S. (Moscow), Independent Researcher, Member of ICOMOS. E-mail: olia85@list.ru. 